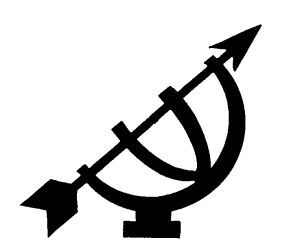

\title{
Gedenken: over de eerste en de tweede geschiedenis
}

\author{
Jacob Klapwijk
}

Emeritus: Moderne en Systematische Wijsbegeerte

Vrije Universiteit

\section{AMSTERDAM}

E-pos: jklapwijk@hetnet.nl

Dit artikel draag ik op aan mijn overleden vriend Theo van der Merwe, die als geen ander de geschiedenis van het christelijk denken een warm hart toedroeg. Hiermee gaf hij op voorbeeldige wijze aan wat ik in dit artikel versta onder gedenken.

\section{Abstract \\ Commemoration: on the first and second history}

In this article a basic distinction is made between the first and the second history. The "first history" is taken as an example in which to indicate history as we experience it from within, on the basis of historical interest. The "second history" would then be history as academic professionals construct it on the basis of historical and critical research of the facts. The question that arises is: How does the historical interest that is typical of the first, lived and experienced history, relate to the historical-critical investigation of the facts that have become determinative for the second, i.e. constructed history? In the following sections I first and foremost pay attention to the human ability to commemorate; commemoration appears to be a specific expression of historical interest. Next, I make note of the difference between significant and small historical narratives and I criticise Fukuyama's view of history. I furthermore analyse the dialogical and critical character of commemoration, describing more precisely this commemoration as an anamnetic experience. I continue by focusing on the romantic misconception of commemoration and on the crucial role of the stranger within the gates. In the following section I contrast the anamnetic and the academic history as an experienced versus a constructive history: is the latter value-free? Finally I come to 
the conclusion that the second history, as a historical construction, can be seen as an indispensable contribution to commemoration, i.e. to our intimate dealing with the first history.

\section{Opsomming}

\section{Gedenken: over de eerste en de tweede geschiedenis}

In dit artikel wil ik een principieel onderscheid maken tussen de eerste en de tweede geschiedenis.1 Onder "eerste geschiedenis" versta ik de geschiedenis zoals wij haar van binnenuit ervaren op grond van historische interesse. De "tweede geschiedenis" is dan de geschiedenis zoals de academische wetenschap haar construeert op grond van historisch-kritisch feitenonderzoek. En de vraag rijst: hoe verhouden zich beide geschiedenissen? Ter beantwoording van deze vraag schenk ik allereerst aandacht aan het vermogen van de mens om te gedenken; gedenken is een specifieke uiting van historische interesse. Dan attendeer ik op het verschil tussen grote en kleine geschiedverhalen en kritiseer ik Fukuyama's beeld van de geschiedenis. Daarop analyseer ik het dialogische en kritische karakter van gedenken; ik belicht het gedenken als een anamnetische ervaring. Vervolgens vraag $i k$ aandacht voor de romantische misvatting van gedenken en voor de spilfiguur van de vreemdeling binnen de poorten. In de volgende paragraaf contrasteer ik de anamnetische en de academische geschiedenis als doorleefde versus constructieve geschiedenis; is de laatste waardevrij? Aan het slot concludeer $i k$ dat de tweede geschiedenis te zien is als een onmisbare bijdrage tot het gedenken, d.i. onze intieme omgang met de eerste geschiedenis.

\section{Inleiding: historische interesse}

Wij, mensen, zijn van nature vertrouwd met de dingen die we om ons heen aantreffen. Wij weten hoe je lucht inademt, dingen optilt, kleren moet aantrekken, water kunt drinken, en een toetsenbord bedient. Ons bestaan is, zo zou men kunnen zeggen, van huis uit inter-esse in de letterlijke zin van het woord: een zijn-tussen de dingen, een betrokken-zijn-op de wereld. Ons bestaan is vooral historische interesse, een betrokken-zijn-op het tijdelijke verloop van de dingen. Wij voelen ons opgenomen in een tijdsgebeuren. De wereld om ons heen verandert en zo ook wij. Tempora mutantur et nos mutamur in illis, zeiden de Romeinen: de tijden veranderen en

$1 \quad$ Ik ben dankbaar voor de kritische kanttekeningen van keurders die de redactie van Koers mij doorgaf bij een eerdere versie van dit artikel. 
wij in hen. Hierin onderscheiden wij ons van de dieren. Ook dieren weten zich één met hun leefwereld maar nooit staan ze stil bij de tijd. Wij wel. Ons bestaan wordt gestempeld door de onverbiddelijke voortgang van de tijd. Mens zijn is een "interesse in de geschiedenis" (Wittram, 1963:1-11).

Interesse in de geschiedenis is iets geheel anders dan vrijblijvende nieuwsgierigheid naar vroegere tijden. Interesse in de geschiedenis is verwikkeld zijn in de geschiedenis. Wilhelm Schapp, een leerling van Dilthey, zei ooit kernachtig: wij zijn "in geschiedenissen verstrikt" (Schapp, 1953). Als mens spelen wij een hoofdrol in ons eigen geschiedverhaal. Interesse in de geschiedenis is een actieve betrokkenheid bij wat er in ons en aan ons gebeurt. Wij leven niet bij de dag. Wij zien achterwaarts en voorwaarts. Wij zijn onderweg en geven ons rekenschap van het afgelegde traject. Wij piekeren en plannen. Wij weten dat aan bijna al onze ervaringen een geschiedenis vastzit. Er zijn belevenissen in opgenomen van onze ouders en grootouders. Er zitten ook tradities in verwerkt die teruggaan tot op de vroegste cultuurvolken. Ik denk hier - wat de westerse mens betreft - aan de Kaukasische half-nomaden uit de Yamna-cultuur (3500 v.C.). Dit waren krachtdadige figuren die het wiel uitvonden en paarden temden, die ook het PIE - de Proto-IndoEuropese oertaal - op formule brachten met behulp van woord- en zinsconstructies waarvan we ons ook tegenwoordig nog bedienen.

Niet voor niets zijn mensen dus fel geïnteresseerd in de verhalen van weleer. Kenmerk van de mens is "het onvermogen te vergeten", zei Nietzsche. ${ }^{2}$ Door de eeuwen hebben mensen hun historie als een levend erfgoed met zich meegedragen om te weten wie ze zijn en om niet in brute barbarij terug te vallen. Gunnen ook wij ons deze moeite? Zijn ook wij doordrongen van het tijdsgebeuren als draagvlak van ons bestaan? Of is geschiedenis slechts rompslomp en ballast? Velen leven in het heden; traditie noemen wij dan de zorg van vroeger, toekomst de zorg voor later. Voor zover historisch besef aanwezig is, leidt dit in ons een verdrongen bestaan. Herinneringen sluimeren, tot wij geconfronteerd worden met een ingrijpende levenskeuze, een ernstige ziekte, of een schokkend verlies. Dan passeert in een flits de trein van het verleden en zoeken wij naar de geestelijke bagage die we ooit meekregen. Dan ontstaat er een proces van consciëntisatie, d.i. bewustwording van wie wij zijn ten overstaan van de geschiedenis. 
Consciëntisatie speelt zich af op individueel maar ook op collectief niveau. Sommigen van ons hebben nog meegemaakt, hoe na de Tweede Wereldoorlog de overgebleven joden terugkeerden uit Auschwitz, volledig beroofd van hun menswaardigheid. Zij moesten zien klaar te komen met hun vernummerd verleden, niet door hun herinneringen te verdringen maar door deze te re-integreren in een nieuw bestaan. Soms lukte dat wonderwel, soms lukte dat pijnlijk niet. Mensen en volkeren kunnen hun geschiedenis kwijtraken. $\mathrm{Na}$ 1945 was de Bondsrepubliek Duitsland decennia lang geschichtslos, economisch hersteld maar niet in staat tot Vergangenheitsbewältigung, niet bij machte om de draad van het verleden weer op te pakken. lets dergelijks deed zich voor in Argentinië na het tijdperk Videla-Viola-Galtieri (1967-1983). Er volgde een vlucht uit de geschiedenis. Alleen de Dwaze Moeders op het Plaza de Mayo in Buenos Aires droegen historisch bewustzijn uit. Tot op de dag van vandaag herinneren Hebe de Bonafini en haar dappere medestrijders aan de waarheid omtrent het verleden. Hoeveel volkeren op het Afrikaanse continent zijn niet eveneens op drift geraakt omdat koloniale bewindvoerders hun historische tradities vernietigden en hun identiteit uitwisten?

Vanaf de dagen van Descartes kost het de westerse wereld de grootste moeite om de band met het verleden te onderhouden. Descartes, de vader van de moderne filosofie, wou zich uitdrukkelijk losmaken van de traditie. Hij stelde het primaat van de rede. De mens moet zich profileren als cogito, autonoom denksubject, en zo de wereld aan zich onderwerpen. Hij moet met hulp van de rede lees wetenschap en techniek - laten zien wie wij zijn: "maîtres et possesseurs de la nature". Het uitgangspunt van Descartes was dus niet de inter-esse van de mens, het verweven zijn met de wereld of het samenzijn van mens en wereld in de ontmoetingsruimte van de geschiedenis, maar de scheiding van subject en object.

Met dit primaat van de rede en deze afscheiding van de wereld rondom, heeft Descartes de moderne mens gestempeld. De mens van tegenwoordig heeft geen intieme band met het verleden, weinig affiniteit met de traditie. Hij zoekt de maat voor zijn bestaan in zichzelf, in praktische zelfverwerkelijking. Geschiedenis ruikt naar kamfer en eau de cologne. Ons jachtig bestaan draait om eigentijdse informatie, het laatste nieuws, de meest recente beursberichten. De historische interesse hebben wij uitgebannen of uitbesteed aan academische professionals. Geschiedkundigen archiveren voor ons het verleden. Zij bestuderen de historische bronnen. Zij vormen zich een objectief oordeel. Zij moeten de feiten 
van vroeger in een causaal verband zetten, en op die manier Descartes' ambitie van rationele controle doorvoeren ook op de glibberige paden van de geschiedenis.

Hier wordt her eerder gememoreerde verschil tussen de eerste en de tweede geschiedenis van belang. Hoe verhoudt zich de historische interesse die zich uit in de eerste of doorleefde geschiedenis, tot het historisch-kritische feitenonderzoek dat bepalend is voor de tweede of constructieve geschiedenis? Wij zullen beide gaan vergelijken. Hiertoe dienen wij een ogenblik stil te staan bij de gedenkwaardigheid van de geschiedenis.

\section{De gedenkwaardigheid van de geschiedenis}

"By the rivers of Babylon we remembered Zion," aldus Psalm 137. Nooit waren de joden zo intens bij hun geschiedenis betrokken als ten tijde van hun ballingschap in Babel. Geen wonder. Pas wanneer wij ons in ons bestaan bedreigd voelen, dringt tot ons door wat geschiedenis voor ons en onze identiteit betekent. Voor veel mensen tegenwoordig is deze dichtregel niet te vatten. Verzekerd van zichzelf, kan de geschiedenis hun gestolen worden. The past has gone. Wie staat er stil bij zijn komaf? Als wij al de historiciteit van ons bestaan overdenken, doen we dat onbewust.

Westerse mensen hebben een haat/liefde-verhouding tot de geschiedenis. Historisch besef wordt verdrongen. Het wordt alleen opgerakeld bij een keerpunt in ons bestaan, op een moment van bezinning in de heksenketel van de tijd. Dan overvalt ons de vraag: wie ben ik, waar kom ik vandaan, en waarheen ben ik onderweg? Dan overdenken wij ons levensverhaal, niet als een opgeleukt oudejaarsoverzicht maar als moederbodem van ons bestaan, als speculum historiale, een spiegel waarin wij onszelf als deelnemer in de geschiedenis in de gaten krijgen. Deze keerzij van het leven treedt af en toe naar voren, bij voorbeeld in tv-programma's met roerende verhalen van mensen die ooit gescheiden werden van hun familie en nu wanhopig op zoek zijn naar hun roots. Of in de hadj, de indrukwekkende bedevaart van miljoenen moslims naar Mekka, het brongebied van hun religie. Of in de fanatieke liefhebberij van vergrijsde pensionado's die zich wijden aan stamboomonderzoek, door arrogante historici meesmuilend "geslachtsziekte" genoemd. Inkeer tot de geschiedenis lijkt ver van huis te voeren. Soms blijkt ze de kortste weg naar onszelf.

$\mathrm{Er}$ is reden mij in de geleefde geschiedenis bewust te positioneren. Ik ben namelijk als mens door de geschiedenis geconditioneerd, 
maar niet gedetermineerd! Ik word pas gedetermineerd, drijfhout op haar golven, als ik haar stuwkracht over me heen laat komen. Vrijheid is zelfverwerkelijking, en zelfverwerkelijking moet ik niet aan de geschiedenis onttrekken maar op de geschiedenis veroveren. Naarmate ik zicht krijg op het pad waarlangs mijn leven zich ontwikkelde, hervind ik mijzelf, tonen zich alternatieven, en ontstaat er ruimte voor de vraag hoe ik mijn weg wil vervolgen. Het is met het oog op morgen dat ik mijn vingers probeer te krijgen achter wat gister geschiedde.

Natuurlijk, dit alles lukt slechts ten dele. Wie peilt de invloed van opvoeding en onderwijs, taal en moraal, en de impact van de media op een kinderziel? Wie zal ooit achterhalen welke kwellingen slaven, lijfeigenen, maar ook Jan met de pet en Marieke met haar boezeroen, de eeuwen door hebben moeten doorstaan? Historische herinneringen huizen voor een niet gering gedeelte in de kelders van de geest, ook in de keldergewelven van ons collectief bewustzijn. Breken die kelderdeuren open, dan volgt er vaak een vloedgolf van protest, ja, dan verslindt de revolutie soms haar eigen kinderen. In Frankrijk viel vijf jaar na de bestorming van de Bastille het hoofd van de grote instigator Robespierre. In Bolivia werd Che Guevara verlinkt door de boeren die hij kwam bevrijden. En toch, er zijn tijden waarin geschiedenis transparant wordt en mensen terugkeren tot de wortels van hun bestaan. Zoiets gebeurt als streekbewoners in een regionaal museum zichzelf herkennen. Of als minnaars in vergeelde liefdesbrieven hun diepste gevoelens hervinden. Of als gelovigen zich weten aangesproken door een troostwoord uit de Bijbel. Of als een volk na jaren van onderdrukking zijn vrijheid herwint.

Deze doorleefde omgang met het verleden in de doorleefde of "eerste geschiedenis" duid ik aan met het sleutelwoord gedenken. Waarom dit woord? Geen geestelijke inspanning is zo gespitst op het binnenhalen van historische betekenissen als de daad van het gedenken. Gedenken is niet een of andere psychologische competentie die je kunt activeren bij een herdenkingsplechtigheid. Gedenken is een wezenskenmerk van de mens die zich verwerkelijkt in de geschiedenis, aldus Gadamer. ${ }^{3}$ Onder gedenken versta ik de innerlijke toe-eigening en bewuste verwerking van wat

3 "Es wäre Zeit, das Phänomen des Gedächtnisses aus seiner vermögenspsychologischen Nivellierung zu befreien und es als einen Wesenszug des endlichen-geschichtlichen Sein des Menschen zu erkennen," aldus Gadamer (1965:13). 
zich in de geschiedenis voordeed als van bepalende betekenis voor ons op onze weg naar de toekomst.

Ik zeg niet dat het woord gedenken in de omgangstaal precies samenvalt met mijn definitie. Ik gebruik het woord a potiori, bij wijze van voorkeur. Ik koester het omdat ik geen ander woord ken dat de inter-esse bij de eerste geschiedenis zo nadrukkelijk tot uitdrukking brengt. Zeker, er zijn verwante woorden, zoals overdenken, herdenken en nadenken over. Er zijn vergelijkbare termen, zoals "zich herinneren", "zich te binnen brengen", "zich voor de geest halen", "zich bewust maken", "op zich laten inwerken", "ter harte nemen", "overwegen", "stilstaan bij", "zich bezinnen op", "memoriseren" en "mediteren". Op zijn tijd zijn al die woorden bruikbaar. Maar sommige zijn nogal banaal; herinneringen hechten zich vaak aan onbenulligheden. Andere zijn nogal plechtstatig; herdenkingen gaan vaak gepaard met vlaggen, paarden en uniformen. Nog weer andere expressies zijn puur feitelijk; zo kan ik de graven uit het Huis van Holland (885-1299) memoriseren maar ze doen mij weinig of niets. Het woord gedenken en misschien ook het woord herdenken liggen voor mij op een apart niveau. Gedenk ik een persoon of herdenk ik een gebeurtenis, dan richt ik mij op de betekenis die deze persoon of dit gebeuren voor mij zou kunnen hebben.

Gedenken zet ook de toon als ik ogenschijnlijk andere dingen doe, als ik loop door de binnenstad van Amsterdam of als ik luister naar de muziek van Mahler of als ik lees in de dialogen van Plato. Hoe verschillend zulke activiteiten ook zijn, er is betrokkenheid op iets wat zijn historische context overstijgt en betekenis krijgt voor mij. Alsof voor een ogenblik de kloof tussen verleden en heden wordt gedicht. Gedenken of herdenken voltrekt zich in rituelen, in rouwdiensten en feestvieringen, in missen en vespers, parades en protestdemonstraties, een voettocht naar Rome en een pelgrimage naar Santiago di Compostella. De kern van elk ritueel is inkeer tot het hart van de geschiedenis.

Wie gedenkt, verdiept zich in de intieme zin van de geschiedenis. Gedenken vergt inkeer en openheid beide. Ik keer in tot mezelf, en al doende realiseer ik mij hoezeer mijn bestaan verknoopt is met het bestaan van anderen. De biografie van mijn bestaan omvat familievetes, dorpsverhalen, streekfolklore, volksgeschiedenis, kerkhistorie en wat niet al. Een vreemde gewaarwording. De kortste weg naar mijzelf loopt via anderen. Hoe meer ik het verhaal van mijn leven met anderen weet te delen, hoe beter het mij lukt mijn eigen identiteit gestalte te geven. 
Gedenken voltrekt zich allereerst in de persoonlijke levenssfeer, in de kring van intimi, als we stilstaan bij een verjaardag, bladeren in een fotoalbum, neuzen in vergeelde papieren, een droogbloem bewaren, of een kinderlied in herinnering roepen. Maar het voltrekt zich ook als een gemeenschapsgebeuren, in het koesteren van onze taal en cultuur, in respect voor tradities en sociale instituties, en in rites de passage rondom geboorte, huwelijk, ziekte en dood. Gedachtenis manifesteert zich ook in het publieke domein, in dodenherdenkingen en vieringen van speciale dagen, aangeduid als Independence Day, de grote Revolutie, Remembrance Day, enz. leder land heeft monumenten van nationale trots, elke kerk haar heiligenkalender, iedere universiteit haar dies natalis.

Heeft de moderniteit altijd weinig affiniteit getoond met de geschiedenis, tegenwoordig zien we een kentering optreden. In de postmoderne belevingswereld is gedenken weer helemaal "in". Formele plechtigheden zijn niet erg in trek maar er gebeurt van alles in wat men aanduidt als "wilde devotie". Opeens zie je weer stille tochten, een wave in een stadion, een bloemlegging door kinderen, flakkerende kaarsjes, opstijgende ballonnen, nieuwe rituelen bij rampen en ongelukken. Party's worden aangekleed met billboards waarop de jubilaris zijn feestgangers verwelkomt met een big smile. Zolderkamertjes worden ingericht met posters van popsterren. Fans metamorfoseren zich tot look-alikes van Michael Jackson of Madonna. Ook de covers van cd's en de websites van cyberspace spelen in op een behoefte aan commemoratie van celebrities. Mensen trekken weer en masse naar Lourdes of andere oorden van echte of vermeende genade, waaronder Elvis Presley's Graceland in Memphis.

Eigenlijk is gedenken modern noch postmodern. Veeleer is het een wezenstrek van de mens als zodanig. In niet-westerse volkeren en schriftloze culturen is de drang om te gedenken zelfs vele malen sterker dan bij ons. Oeroude mythen worden daar doorverteld van kind op kind. Barden bezingen de heldendaden van roemruchte krijgers. Geslachtsregisters bieden houvast en identiteit. De Ilias en de Odyssee, de kolossale dichtwerken van Homerus, werden vierhonderd jaren lang met ritmische precisie doorverteld alvorens ze, in de achtste eeuw v.C. op schrift werden gesteld. Eeuwenlang hebben mensen zich de inzettingen der ouden ingeprent rondom een knoestige eik, binnen een kring van megalieten, voor een steile obelisk, in de dans van draaiende derwisjen, onder de bezweringsformules van sjamanen, of tijdens de jaarlijkse processie van wit geklede priesters over de via sacra. Vanaf het pre- 
columbiaanse Amerika tot in China werden grandioze offerfeesten gevierd als verbeelding van het verloren Oerbegin, het grote Nieuwjaar, de koningsmare van Copán, de glorie van de Sjang- en Tsjo-dynastie.

Boze tongen beweren dat primitieve natuurvolken geen geschiedenis hebben en slechts het ritme van dagen, seizoenen en jaren volgen. Het mocht wat! Veeleer beleven deze volken de band met het voorgeslacht zo intens dat de wanden van verleden en heden samentrekken in een mythisch wereldbeeld. Geesten van vroeger varen rond in het land der levenden. Levenden vereenzelvigen zich met de totem van de stam of keren terug tot de ordeningen van weleer. Aanschouwelijk is dit uitgewerkt in het vijftigste jaar als jubeljaar zowel bij de Maya-indianen als onder de stammen van Israël. Het jubeljaar was het jaar waarin orde op zaken werd gesteld, en de ordeningen van de oertijd weer terugkeerden. En toch, hoe indringend de historische gedachtenis daar ook is, in de mythische tijdsbeleving is iets cruciaals verdwenen: de historische distantie en haar mogelijke overbrugging. Het oerbegin lonkt maar de tussentijd is weggevallen. Het onderweg-zijn van de mens stagneert. Inkeer wordt terugkeer, restauratie van de toestand van weleer. In de drang naar restauratie gaat de creativiteit van het gedenken verloren.

De riten en mythen van niet-westerse volkeren vertellen ons: gedenken is meer dan een eigentijdse aangelegenheid, het is een noodzakelijke terugkeer tot het verleden als moederschoot van ons bestaan. Maar het gevoel van verworteling dient wel handen en voeten te krijgen in het heden, vruchtbaar te worden gemaakt voor een betere wereld.

\section{Grote en kleine verhalen: Fukuyama's vergissing}

De eerste geschiedenis geeft het geheim van haar zin niet anders prijs dan langs de weg van het gedenken. Gelukkig steunt het gedenken niet enkel op persoonlijke herinneringen; die zijn vaak al te vluchtig. Het steunt ook op instituties en overleveringen. Het steunt vooral op doorvertelde verhalen. Er is echter een enorm verschil tussen grote en kleine verhalen.

Wie gedenkt, zoekt de zin van wat gebeurde, maar zit niet te wachten op een grandioos verhaal, dat de totale geschiedenis wil omspannen. Dit laatste is onmogelijk. Wie dringt door in de prehistorie van het mensdom, zeg, in het leven van Lucy, een stammoedertje van mensachtigen drie miljoen jaren geleden, van 
wie Donald C. Johanson in 1974 in Ethiopië de fossiele resten terugvond? Wie peilt wat er omging in Homo sapiens, die vanaf prehistorische tijden - een kleine tweehonderd duizend jaar geleden - rondzwierf in zuidelijk Afrika? Wie doorgrondt de drijfveren van Ötzi, de Europese oerjager die vijf millennia terug in de Oostenrijkse Alpen werd achtervolgd, zich verstapte, en verglaasde in gletsjerijs? $\mathrm{Ja}$, wie achterhaalt de levensgang van de miljarden mensen die tegenwoordig de aardbol bewonen en ontcijfert de zin van hun vaak kommervol bestaan?

Het zijn idealistische systeemdenkers en positivistische sleutelaars aan een maakbare samenleving die het Grote Plan van de wereldgeschiedenis in kaart hebben gebracht. Maar hun megaverhalen deugen voor geen meter. Zij degraderen vroegere generaties tot wegbereiders voor de moderne mens, mest op de akker van de toekomst. Alsof het harde leven van jagers, verzamelaars, schaapherders en landbouwers geen betekenis had voor hen zelf en hun omgeving! Grote verhalen missen deernis omdat gedachtenis ontbreekt. Ze missen waarheid omdat ons, pelgrimerend in de geschiedenis, overzicht over de geschiedenis ontbreekt.

Op universele historie rust terecht een transcendenteel taboe. Wie gedenkt moet ideologische grootspraak deconstrueren, wereldgeschiedenis afbreken tot gebeurtenissen van een herkenbaar formaat. Wie gedenkt, tast naar een levensgeheim, gebogen over een wieg. Of hij overdenkt de zegeningen van een geslacht, in familieverband verhaald. Of hij memoreert het lijden van een volk, door traditie bemiddeld. Gedenken is luisteren naar levensverhalen, petites histoires. Geen breed exposé maar een reeks vertellingen, klein genoeg voor ons bevattingsvermogen. Wie gedenkt, wil niet verklaren maar verwerken, d.i. in het heden zin geven aan wat zich in het verleden voordeed. Hoe houden kinderen de nagedachtenis van hun ouders in ere? Wat doen Duitsers met het gedachteniscentrum in Plötzensee, waar nazi's hun tegenstanders executeerden? Hoe gaan westerse landen om met hun koloniaal verleden? Hoe doen gelovigen recht aan Franciscus van Assisi en zijn ideaal van navolging van Christus door armoede en liefde voor de natuur?

De boodschap van de geleefde geschiedenis verwatert snel. Vandaar dat wij haar objectiveren, d.i. vastleggen in verhalen, liederen, spreuken en familiegeschiedenissen. Wij persen haar in symbolen van hout, steen of brons. Grafheuvels, gedenkstenen, standbeelden, de Gouden Koets in Den Haag en de Eiffeltoren in 
Parijs stralen een boodschap uit, evenals de vaderlandse driekleur en de Olympische medaille. In het gedenkteken verheft zich een ooit beleefde betekenis in een gestolde vorm. Objectivering lijkt een verlies maar ze is een winst, want ze verduurzaamt de herinnering en geeft het verhaal een wereldwijde actieradius. Hoeveel verdrukten uit Europa, ingescheept voor de Nieuwe wereld, lieten niet een traan toen ze aan gene zijde van de Atlantische oceaan in de Hudsonbaai het Vrijheidsbeeld zagen verrijzen?

Ook in de bijbel klinkt de roep om te gedenken. Van de aartsvader Jacob wordt verhaald dat hij in uitzonderlijke situaties een gedenksteen oprichtte, onder meer bij zijn ontmoeting met God te Bethel (Gen. 28). Israël moest bij zijn entree in het Beloofde land twaalf keien uit de Jordaan meenemen ter gedachtenis, opdat een komend geslacht zou vragen: "Wat hebben deze stenen te betekenen?" (Joz. 4) Veel psalmen zijn een oproep om de grote daden van God te gedenken (Ps. 105). En Jezus stelde vlak voor zijn dood het Heilige Avondmaal in met de breking van brood en met de woorden: "Dit is mijn lichaam. Doet dit tot mijn gedachtenis." 4 Kortom, in de eucharistieviering is Gods heil in de geschiedenis verankerd en toch vlakbij; je kunt het aanraken, proeven en smaken.

Gedenken is zodoende een kernmoment in de overdracht van cultuurwaarden. Het is geen conservering van traditie, veeleer een worsteling met de tijd. Door te gedenken nemen wij de traditie voor eigen rekening, worden wij erfgenamen en erflaters van beschaving ineen. Wij interioriseren ervaringen en herformuleren ze met het oog op de toekomst. Sommigen zeggen: gedenken is omzien naar het verleden. De progressief katholieke Acht mei-beweging in Nederland formuleerde het eens veel mooier. Ze zei: gedenken is omzien naar de toekomst.

In zekere zin kennen ook dieren cultuuroverdracht. Ze passen zich aan nieuwe omstandigheden aan maar ze nemen hun verleden niet of nauwelijks mee. Bij hogere diersoorten leren volwassen exemplaren aan jongere de kunst van het jagen en overleven. Bij primaten tref je zelfs overdracht van individueel verworven kennis aan. Ooit werd geconstateerd dat in een groep chimpansees een ouder wijfje zonder status tijdens een grote droogte lotgenoten leidde naar een waterbron waar zij slechts weet van had. Toch 
schrijven dieren geen geschiedenis. Bevers bouwen de eeuwen door dezelfde dam. Lemmingen storten zich bij overbevolking naar vast patroon in zee. Vanwaar dit stereotiepe, mimetische gedrag? Dieren gedenken niet.

Blijven wij onze petites histoires doorvertellen, ook in een nieuw millennium? De mogelijkheden lijken gunstig. Digitale media brengen het verleden in de huiskamer. Zaken die vroeger werden weggemoffeld, brengen wij tegenwoordig naar voren als een deel van onze identiteit. De uitroeiing van Indianen legt een claim op het Amerikaanse geweten. De slavernij in Suriname bezwaart het Nederlandse gemoed. Internationale banken moeten zich verantwoorden voor hun beheer van joodse goederen. Troostvrouwen presenteren een rekening bij het gouvernement in Tokio. De ontboezemingen van lady $\mathrm{Di}$ aan Martin Bashir in het BBCinterview van 20 november 1995 kluisterden twintig miljoen Britten aan de beeldbuis. De heruitzendingen die volgden betrokken tweehonderd miljoen aardbewoners bij de vraag of de monarchie met al haar strapatsen nog zin heeft in onze tijd.

Dus komt de moderne informatie- en communicatietechnologie het gedenken ten goede. Of niet? Het gevaar is niet denkbeeldig dat in de stortvloed van informatie de zinoriëntatie verloren gaat en historische kennis verengt tot commerciële prietpraat. Verhalenvertellers zijn een uitstervend ras geworden. Ouders zetten hun drukke kinderen voor de dvd-speler. Niets lijkt opgewassen tegen het fast food dat wordt opgediend door in te pluggen op internet. De productie van historische reeksen is tegenwoordig big business in uitgeversland, maar bevredigt meer de nieuwsgierigheid dan de gedachtenis. En toch werkt alle vrijkomende kennis als een gongslag in de tijd. De atoombom die 6 augustus 1945 Hiroshima in de as legde, brandt tegenwoordig dieper in het geweten dan zestig jaar terug. Het Anne Frankhuis in Amsterdam, in 1960 opgezet als een mogelijke trekpleister voor toeristen, is onder jongeren uitgegroeid tot een huis van wereldwijde bezinning, waar in 2005 966.000 bezoekers binnenliepen. In datzelfde jaar riepen de Verenigde Naties de 27e januari - de dag waarop Auschwitz werd bevrijd - uit tot Holocaust Memorial Day.

Daarom verwerp ik het neoconservatieve betoog dat Francis Fukuyama ons voorschotelde in Het einde van de geschiedenis en de laatste mens (Fukuyama, 1992). In dit boek poneert Fukuyama dat door recente maatschappelijke ontwikkelingen, waaronder de val van de Muur in 1989 en de sindsdien gecoördineerde opmars van wetenschap, techniek en kapitalistische economie in heel de wereld 
de liberale democratie gezegevierd heeft als politiek-economische maatschappijvorm. Hiermee hebben we zijns inziens het einde bereikt van de eeuwenlange strijd tussen ideologieën - het einde van de geschiedenis. Gegeven de spelregels van democratisch overleg en liberale tolerantie, hoeft niemand zich nog druk te maken over het verschil tussen goed en kwaad dat vroeger de gemoederen verhitte, de mensen verdeelde, en de wereldvrede bedreigde. Voortaan bekommeren we ons slechts om gezondheid, veiligheid en privé-geluk.

Fukuyama's concept van de geschiedenis is een modern megaverhaal, een westerse vooruitgangsmythe, de zoveelste poging om Hegels idee van Universalgeschichte te overtroeven. Het is een droom die op 11 september 2001 door de "war on terror" wreed verstoord werd. Op één punt heeft de man echter gelijk. De link die hij legt tussen het einde van de geschiedenis en de laatste mens is zo gek nog niet. Stel, de huidige maatschappijordening zou vanzelfsprekend worden en mensen zouden genoeg hebben aan zichzelf, dan verstomt de dialoog met het verleden, dan vindt geen cultuuroverdracht meer plaats. Dan komen dromen aan haar einde en klapt de geschiedenis dicht. Zonder gedachtenis gaan mensen lijken op lemmingen.

\section{Het dialogische en kritische karakter van gedenken}

Mensen hebben iets met de eerste of doorleefde geschiedenis, want zij gedenken. Dit gedenken uit zich op vele manieren, in stemmingen, houdingen, gedragingen en vormgevingen aan de toekomst. In deze paragraaf stip ik tien wezenlijke kenmerken aan.

- Gedenken is een innerlijke ervaring. Het is de poging om de geschiedenis niet maar feitelijk vast te leggen maar haar te interioriseren. In het gedenken verwerkelijk ik haar vormende kracht in de historiciteit van mijn eigen bestaan. Ik toon mij bereid lering te trekken uit wat mij of ons overkomen is. Geschiedenis is "Er-innerung", zei Hegel, een in ons bewaren en kunnen oproepen van wat ooit in de tijd voorbijkwam en verloren leek te gaan (Hegel, 1952:564). 5 Het is een innerlijke toe-eigening, niet door overmeestering of geweld maar door ontvankelijkheid. Ik

$5 \quad$ Ik neem afstand van de idealistische context van deze woorden, d.i. Hegels opvatting dat de herinnering van de eindige geesten de weg is die ons voert naar het einddoel van de geschiedenis, de apotheose van het zelfbewustzijn van de absolute geest. 
stel mij open voor wat het geleefde leven mij te bieden heeft. Ik wordt geraakt door wie of wat mij aanspreekt, zoals bij voorbeeld Tolstoj en Mahatma Gandhi op een keerpunt in hun leven geraakt werden door de radicale Bergrede van Jezus.

- Gedenken is een hermeneutische ervaring. Willen wij de geschiedenis interioriseren, dan zullen wij haar zin moeten duiden. Uitgangspunt van de hermeneutiek, d.i. theorie van het verstaan, is dat mensen en gebeurtenissen, hoezeer door een tijdskloof van ons gescheiden, hun betekenis niet verloren hebben. Door te gedenken, peilen wij deze betekenis om haar te verstaan, te vertolken en toe te passen in het heden. Wij tillen betekenissen over de drempel van de tijd en geven ze een nieuwe uitleg in het licht van nu. Op het Tweede Vaticaanse concilie (1962-1965) weerklonk de roep tot aggiornamento. Inderdaad, ook kerkelijke tradities van twee millennia vragen om vernieuwing. Het verleden dient geïnterpreteerd te worden in dienst van het heden.

- Gedenken is een dialogische ervaring. In het gedenken toont zich het besef dat mensen mensen nodig hebben om zelf mens te worden. Naar de monumentale woorden van Martin Buber: "Ich werde am Du." Ik word aan (in de ontmoeting met) het Gij (Buber, 1974:18). Gedenkend ben ik niet langer een autonoom subject. Er vindt wisselwerking plaats tussen mij en anderen, heden en verleden. Ik bekijk het heden in het licht van het verleden maar ook het verleden in het licht van het heden. Verleden en heden zijn tekst en context voor elkaar. Beurtelings vormen ze de achtergrond waartegen het andere wil worden uitgelegd. Men noemt deze interactie een hermeneutische cirkel. Eigenlijk vormt ze een voortrollende schijf. Want in de dialoog met het verleden komen de gesprekspartners beide in beweging. Door de historie op mij te laten inwerken, verandert er iets in mij, en door die veranderingen in mijzelf valt er ook weer ander licht op de historie. Ik geef twee voorbeelden.

Eerste voorbeeld: de herdenking van de Tweede Wereldoorlog. In de eerste decennia na WO II spitsten de herdenkingen in tal van landen zich toe op de strijd tegen een totalitair regiem, op de viering van staatkundige en geestelijke vrijheden, en op wederopbouw. Maar voor het mateloze leed dat de slachtoffers van het regiem was aangedaan, was amper aandacht. Otto Frank kon voor het nu wereldberoemde Dagboek van zijn dochter Anne in Europa pas na jaren een uitgever vinden. Tegenwoordig herdenken wij in WO II vooral ook de strijd tegen tendensen die 
ons nu verontrusten: racisme, rechteloosheid, vreemdelingenhaat en onverdraagzaamheid.

Tweede voorbeeld: Willem de Zwijger, in Nederland bekend als de Vader des vaderlands! Die erenaam verdient Willem van Oranje zeker. Tegenwoordig hebben de landen van Europa zich verenigd in de Europese Unie. Verbleken hierdoor niet de contouren van het vaderland en van de Vader des vaderlands? Geenszins, maar wel is de zeggingskracht van de Zwijger veranderd. Eerst in onze tijd gaan de ogen ervoor open hoezeer het staatsmanschap van deze Oranje reeds in de $16 \mathrm{e}$ eeuw Europese afmetingen had. Oranje was een visionair, zijn tijd ver vooruit. Over de grenzen van de Verenigde Republiek streed hij "pro religione et libertate". Niet zonder succes, want ondanks het steile calvinisme werd Nederland een toevluchtshaven voor dissidenten uit tal van landen.

- Gedenken is een symboliserende ervaring. Herdenking hecht zich aan symbolen. Een symbool is een zinnebeeld, iets zinnelijks dat het onzienlijke verbeeldt en zo bemiddelt tussen een zichtbaar heden en een onzichtbaar verleden. Neem de huwelijksring. De belofte van trouw verklonk voorgoed maar de band van trouw blinkt nog in goud ter gedachtenis. Maar ook doop en avondmaal, vlag en vaandel, ereteken en monument, kleding en haardracht, instituties en folklore, moskeeën en synagogen, fungeren als symbolen die geladen zijn met betekenissen die willen worden opgemerkt. 6 Zijn niet alle geschiedverhalen symbolen van het verleden? Ze houden ons een spiegel voor van wie wij zijn, als mens, volk en wereldgemeenschap.

- Gedenken is een receptief-productieve ervaring. Wij stellen ons open voor het verleden omwille van het heden en de toekomst. Leven uit herinnering mondt uit in leven uit verwachting. "Be kind to your memories!" impliceert "cherish your ideals!" Historische receptie beoogt conservatie maar evenzeer creatieve vernieuwing. Wie gedenkt, peilt de afstand tot het verleden en de bewegingsruimte die deze biedt. Dat is de vruchtbaarheid van de geschiedenis. Gedenken is een gouden kans om uit haar tredmolen te stappen onder het voornemen: dit nooit weer! Alle

6 Het symbool is in het historische proces zelf aan re-interpretatie onderhevig. Denk aan het kruis van Christus, in handen van prelaten, kruisridders, grootinquisiteurs, Rozenkruisers, en het Rode Kruis. 
grote hervormers waren zich bewust van hun plaats en roeping in de geschiedenis. Als er één ding is waaraan totalitaire regimes een broertje dood hebben, dan is het gedenken. Niet zonder reden nam de Taliban in maart 2001 in Afghanistan de twee Bamiyan Boeddha-beelden uit 400 n.C. aan de oude Zijderoute onder vuur. Die iconoclasten beseften: beelden bergen betekenis. Zodra een totalitair regiem zich settelt, komen boeken op de brandstapel, gaat creativiteit aan de ketting, en wordt gedachtenis taboe.

- Gedenken is een selectieve ervaring. "Gedachtenis is niet gedachtenis überhaupt en voor alles", zegt Gadamer (1965:13). Inderdaad, gedenken is niet een algehele opfrisbeurt van het geheugen, het is geen mnemotechniek. Het is speuren naar dingen die vastgehouden maar soms ook vernieuwd moeten worden. Wij moeten bereid zijn stukken van het verleden waar wij niets mee kunnen als ballast af te werpen. "Er is een mate van slapeloosheid, herkauwen en historische zin waarbij het levende ... schade oploopt en tenslotte te gronde gaat," waarschuwt Nietzsche (1963:2.1). Pas wel op voor relativisme. Met Troeltsch en Toynbee, Jaspers en Voegelin 7 ben ik van mening dat er in de geschiedenis der mensheid brandpunten van zingeving zijn die blijvend oplichten. Ik denk aan de karrenvracht aan betekenissen die ligt opgetast in de klassieke beschavingscentra van Thebe, Jeruzalem, Athene, Rome en, om niet meer te noemen, de oudChinese keizersstad Xi'an.

- Gedenken is een controversiële ervaring. Wat wij gedenken is vatbaar voor velerlei uitleg. De oprichtingsdatum van de staat Israël, 14 mei 1948, is voor Israëli's een nationale feestdag maar voor Palestijnen "al-Nakbah", "dag van het Onheil". De Europese grondwet zou een verwijzing moeten bevatten naar de joodschristelijke grondslagen van de Europese Unie maar ziedaar, in de opgeschoonde uitleg van haar seculiere leiders was haar spirituele afkomst niet eens het vermelden waard. Terecht werd deze grondwet afgestemd. Herdenkingen roepen altijd gemengde gevoelens op. Ze kunnen eendracht uitstralen maar ook woede en frustratie. Van die woede en frustratie getuigden de 300000 deelnemers aan de Witte Mars door Brussel op 20 oktober 1996, nadat Marc Dutroux, de kinderverkrachter, was verzeild in een

$7 \quad$ Zie Troeltsch (1961 [1922], hfdst. 4); Toynbee (1946); Jaspers (1949); Voegelin (1956) en (1974). 
dubieuze rechtsgang. Herdenkingen bieden vaak ook openingen aan bedenkelijk nationalisme. Ik denk aan de jaarlijkse Oranjemarsen in Noord-lerland ter viering van de slag bij de Boyne. En werd het indrukwekkende Voortrekkermonument in Pretoria niet geëxploiteerd voor politieke oogmerken? Denk ook eens aan de bedevaarten naar het IJzer-monument in België. En vergeet evenmin de gebedsrituelen bij de Yasukuni-oorlogsschrijn in Japan. De geschiedenis spreekt boekdelen; maar wat de geschiedenis te zeggen heeft, ligt niet voor het oprapen.

- Gedenken is een kritische ervaring. Gedenken is geen koestering van het verleden. Wij herdenken de Tweede Wereldoorlog maar koesteren hem niet. Gedenken involveert een kritische afweging die noch met volledige affirmatie noch met volstrekte negatie van het verleden samenvalt. Hier lag in de vorige eeuw de achillespees van de marxistisch getinte Kritische theorie. Walter Benjamin, Adorno en Horkheimer zagen de gedachtenis als een laatste wijkplaats voor de ervaring in een wereld zozeer overwoekerd door kapitalistisch winstbejag, dat men haar nog slechts kon ontlopen in een vreemde mengeling van messiaans verlangen en volstrekt negatieve kritiek. Die negativiteit deel ik niet. Echte kritiek vergt een gewetensvol afwegen voorbij negatie en affirmatie. Wij vallen het verleden niet genadeloos af en wij vallen het niet klakkeloos bij. Een liberaal, een marxist en een romanticus denken verschillend over de symbolen van het verleden, zo ook een christen, een moslim en een atheïst. De op 11 september 2001 door twee Boeings doorboorde Twin Towers van het World Trade Center in New York, door de ontwerpers Yamasaki en Brittiochi nog fraai de hemel in geprezen als "uitdrukking van het geloof in menselijkheid", symboliseerden in feite de triomf van het kapitaal. Althans in het Westen. In andere werelddelen werden ze gehaat als symbool van onmenselijk geweld. Wie gedenkt, moet een kritische keuze maken.

- Gedenken is een norm-georiënteerde ervaring. Wie gedenkt, moet kritisch kunnen kiezen. Dit kiezen vergt een norm, een toetsingsmaatstaf. In eerste instantie is zo'n norm op te diepen uit de geschiedenis zelf. Gedenken bepaalt ons bij mensen die toonbeelden werden van geweldloosheid (Gandhi), van waarheid (bischop Tutu), of zelfopofferende naastenliefde (moeder Teresa). Toch blijkt al gauw, ook deze mensen incorporeerden niet de finale norm. Hun acties waren niet feilloos, hun inzichten tijdgebonden, hun normen een beperkte en vaak ongelukkige uitdrukkingsvorm van wat hen ten diepste voortdreef. Vreemd maar waar, zodra wij vorm geven aan de geschiedenis dan 
verwijzen wij naar normen waarvan de diepste kern de deficiënties van onze historische maatstaven te boven gaat (Klapwijk, 1994:158-192).

- Gedenken is een ervaring van transcendentie. De oude spreuk van Protagoras "de mens is de maat van alle dingen" en het postmoderne adagium "ieder mens zijn eigen waarheid" suggereren dat waarheid niet meer is dan een oprisping van mensen, een functie van tijd en geschiedenis. Zou het gedenken hierop niet afknappen? Waarom zouden wij gedenken wat morgen verouderd en overmorgen vergeten is? Gedenken maakt duidelijk dat waarheid en gerechtigheid geen historische producten zijn, dat ze veeleer de geschiedenis dragen en onder kritiek stellen. Gedenkend tasten wij naar dat wat de voorlopigheid en veranderlijkheid van onze normpatronen overstijgt. Anderen kunnen voor ons wegwijzers worden naar waarheid maar nooit de bron van waarheid. De talloze slachtoffers van geweld - in de 20 e eeuw bijna 200 miljoen volgens een recent rapport van de Wereldgezondheidsorganisatie 8 - roepen om gerechtigheid, maar ook hun appel blijft een gebrekkige verwijzing naar wat dit appel transcendeert. In de geschiedenis ontdekken wij Chiffren, zegt Karl Jaspers, sporen van transcendentie, zegt Meijer C. Smit, al is dit voor beiden meer een zaak van geloof dan van bewijs. Dus noemt Smit de eerste geschiedenis transcendentaal, betrokken op een goddelijke Oorsprong (Smit \& Klapwijk, 1987:100). Ook bij Eric Voegelin is de remembrance of anamnetische meditatie op transcendentie toegespitst. 9 Voor Smit en Voegelin wordt de act van het gedenken een bijna mystieke eenheidservaring, een gebeuren waarin de wanden tussen de eeuwen en culturen wegvallen, en waarin riten en symbolen de zin van gebeurtenissen doen oplichten als goddelijke overmacht. Wat in de "ontmoetingsruimte" van de geschiedenis als betekenisvol verschijnt, is een index van transcendentie.

8 WHO (2002) rapporteert dat in de afgelopen eeuw 191 miljoen mensen door direct of indirect geweld om het leven kwamen, het merendeel burgers.

9 In Voegelin (1966) en (1987) zijn anamnese en herinnering kernbegrippen, verwijzend naar de historie als de primordiale ontmoetingsruimte van mens en wereld. In deze ruimte toont de mens zich ontvankelijk voor gebeurtenissen die hem te boven gaan, waarin God zich manifesteert in symbolen die zin stichten en waarvan een blijvende claim uitgaat op alle mensen. Deze claim voert Voegelin (1956:60) tot de mijns inziens voorbarige conclusie "The nature of man is constant". Zie Buijs (1998:178-188). 
Geven deze tien punten niet stuk voor stuk aanleiding om de innige relatie tussen mens en wereld opnieuw te doordenken? Wij moeten afscheid nemen van Descartes, de filosoof van de moderniteit met zijn scheiding van subject en object, en zijn dualisme van een autonome rede versus een beheersbare wereld. Wij moeten scheidingsdenken veranderen in heelheidsdenken. Wij worden uitgenodigd om met Smit en Voegelin gedenkend in te keren tot de integrale ontmoetingsruimte van de geschiedenis, waarin mensen zin-stichtende gebeurtenissen een plaats geven in hun bestaan. Toch maak ik een kritische kanttekening. De idee van de eerste geschiedenis als ontmoetingsruimte mag niet leiden tot een mystieke vereenzelviging van heden en verleden, of tot de notie dat wij eigenlijk "tijdgenoten" zijn van wie ons voorgingen, een Plato, een Augustinus of wie dan ook.10 De notie van gelijktijdigheid draait uit op conservatisme en onkritische verheerlijking van vroegere tijden. Vereenzelviging met vroeger frustreert de vruchtbaarheid van de geschiedenis, stopt de dialoog met het verleden, en dooft de creatieve zin van het herdenken.

Geven wij niet door het gedenken zo centraal te stellen het moderne beginsel van rationele verlichting prijs? Ruilen wij hier de rede niet in voor obscurantisme en irrationeel gevoel? Dit is niet mijn bedoeling. Wij moeten vasthouden aan het kritische licht van de rede, ook het rationele onderzoek van de historische feiten niet prijsgeven. Maar er is tweeërlei verlichting. De ene is in de geest van Descartes en Kant. De andere is in de geest van Augustinus. Het zou kunnen zijn dat wat Aufklärung heet, verlichting door de rede, niet ontspringt aan een autonoom denksubject zoals verwoord door Kant, maar gedragen wordt door illuminatio, goddelijke verlichting, zoals verwoord door Augustinus. En dat op grond van Psalm 36:10: "In Uw licht zien wij het licht."

10 Smit stelt dat in de eerste geschiedenis de wanden tussen de eeuwen en culturen wijken en allen elkaars gesprekspartners worden. Hij vervolgt bijna lyrisch: "Wie er zijn? Een Plato, Augustinus, Alberti, Poussin, Adam Smith, maar ook de Hellenistische boer, de feodale heer, de geprangde slaaf, ook Ranke, talloos velen! In het perspectief van de continue tweede geschiedenis is het onmogelijk dat zij allen tegelijkertijd aanwezig zijn, doch de eerste geschiedenis heeft hen in staat gesteld elkaars tijdgenoten te worden, voor-goed." (Smit \& Klapwijk, 1987:114-115 - accentuering door Smit \& Klapwijk). 


\section{Het romantische misverstand - de vreemdeling binnen de poorten}

In het gedenken - ik zal voortaan ook spreken van anamnetische ervaring, want anamnese is herinnering - geeft de mens gestalte aan de eerste geschiedenis als doorleefde geschiedenis. Het zou fout zijn uit het gedenken particularistische conclusies te trekken, alsof wij in de eerste geschiedenis volledig worden teruggeworpen op ons eigen levensverhaal of cultuurverleden. Dit particularisme was twee eeuwen terug kenmerkend voor de romantische grondleggers van de historische denkwijze. Zij stelden dat ieder mens organisch is ingebed in de geschiedenis van zijn land en volk. $\mathrm{Hij}$ is een cel in het levende organisme van de volksgemeenschap en het volk is op zijn beurt de historische belichaming van een gemeenzame volksziel. De ziel van een volk zou alle volksgenoten in heden en verleden als met een mystieke band omvatten, en door charismatische leiders worden verwoord in het volkseigen karakter van kunst, literatuur, moraal en godsdienst.

Ik neem afstand van deze organologische gemeenschapsleer. Ze berust op een romantisch misverstand, op biologische metaforen, op de speculatieve veronderstelling dat een historische ontwikkeling te vergelijken is met de organische ontwikkeling van een plant, die zich nooit losmaakt van haar eigen wortels. Herdenken wordt zo een nostalgische aangelegenheid, een inkeer tot de corporate spirit van een natie, een exclusieve oriëntatie op eigen cultuur en godsdienst. Dit herdenken leidt tot conservatisme, etnocentrisme en nationalisme. Het kan zelfs ontaarden in een Blut- und Bodentheorie als van de nazi's.

Er is geen grond om de anamnetische ervaring in te snoeren op het eigen volksverleden. Zeker, wie gedenkt zal in eerste instantie reflecteren op de traditie waarin men staat, maar niet in exclusieve zin. Uniek voor de mens is dat hij opgroeit in een omgeving zonder er geheel mee te vergroeien, zoals een dier met zijn habitat.11 De mens is onderweg, overdenkt zijn verleden maar ook om afstand te nemen en elders leerervaringen op te doen. Vroeg of laat staat hij oog in oog met de vreemdeling binnen de poorten, d.i. die raadselachtige figuur die volgens oud-oosterse opvattingen gast-

11 Taalpsychologen hebben recent geconstateerd dat baby's al in de eerste levensmaanden zich de klanken toe-eigenen van de moedertaal, nog voor het aanleren van woorden. Toch leren ze ook op latere leeftijd vreemde talen. 
vrijheid verdient en recht van spreken heeft.12 De anamnetische ervaring is in deze visie een proces van bewustwording waarin wij ons openstellen voor mensen met een missie van elders.

In de geschiedenis van de mensheid is deze culturele interdependentie een terugkerend patroon. Inheemse mores domineerden duizenden jaren het geestesleven maar, uitgelokt door handelsverkeer of oorlogsgeweld, hebben ook altijd culturele kruisbestuivingen bijgedragen aan de identiteit van volkeren. Reeds in het Laat Paleolithicum onderhielden de Cro Magnon-mensen in Zuid-Europa, blijkens sierstenen in opgedolven graven, ruilrelaties met clans in verre streken. Aan het einde van de IJstijd, toen mammoeten en rendieren met de Noorderzon vertrokken, stelden prehistorische jagers zich open voor landbouw, veeteelt en pottenbakken, cultuurvormen die kort tevoren ontwikkeld waren in de Jordaanslenk en Mesopotamië. Ook de oorlogen tussen Minoërs en Doriërs, Egyptenaren en Nubiërs, Babyloniërs en Assyriërs, Grieken en Romeinen, en de veroveringen van Hunnen, moslims, kruisridders en Mongolen verbreedden de horizont van het gedenken. Zo werden de Minoërs op Kreta onderworpen maar kon de Minoïsch-Myceense cultuur zich op de Peloponnesus verbreiden. De Romeinen verstoorden de Griekse stadstaten maar het hellenisme veroverde het imperium Romanum. De Joden werden verstrooid in de Diaspora maar de Thora bevruchtte de westerse wereld. De Reconquista verdreef de Moren uit het middeleeuwse Spanje, maar de aristotelische filosofie en Arabische geneeskunde nestelden zich aan de topuniversiteiten van Europa.

In een wereld van geweld - dat kan ook het geweld van de reclame zijn - is gedenken een weerloze maar niet vruchteloze aangelegenheid. Druk voert tot zelfbezinning en tegendruk. Het gedenken van Sion verdiepte zich onder de Joden in Babylonische ballingschap tot de Messiaanse vergezichten van Deutero-Jesaja. De plundering van Roma aeterna door Alarik's troepen zette Augustinus aan tot het schrijven Over de stad van God, een monument van wereldhistorische gedachtenis. En om iets heel anders te noemen, de spirituele ritmiek van de Amerikaanse negermuziek moest eerst de vernederingen in het hete Zuiden van de VS doorstaan, alvorens ze kon beginnen aan een onstuitbare opmars naar de wereld van gospel, soul en beat.

12 Ook in de bijbel komen we de vreemdeling binnen de poorten meer dan eens tegen (zie b.v. Ex. 20:10; Deut. 14:21). 


\section{Anamnetische en academische geschiedenis}

Wij dienen de anamnetische interesse, die gestalte krijgt in de historische gedachtenis, scherp te onderscheiden van de geschiedwetenschappelijke interesse, die gestalte krijgt in historisch of (beter gezegd) historicaal onderzoek. Het historicale onderzoek omvat de systematische en kritische benadering van het verleden door het ontsluiten van historische bronnen, het toetsen van historische feiten, en het zoeken naar intentionele dan wel causale verklaringen voor de gebeurtenissen van weleer.13 Het gaat hier in eerste instantie om de professionele werkwijze van geschiedkundigen, maar men treft ook historische onderzoekingen aan in verwante disciplines zoals de paleografie, culturele antropologie en de sociale disciplines.

Zoals de anamnetische interesse zich profileert in de eerste geschiedenis, zo articuleert de historicale interesse zich in de tweede geschiedenis. Toch ligt het verschil tussen wat men onder eerste en tweede geschiedenis dient te verstaan, bepaald niet vast. Deze onduidelijkheid manifesteert zich bij voorbeeld in de opvattingen van Meijer C. Smit, voorheen geschiedenisfilosoof aan de Vrije Universiteit te Amsterdam; ik noemde hem al eerder. In 1970 schreef hij een van zijn meest indrukwekkende essays: "Beschouwingen over de geschiedenis en de tijd der geschiedenis", opgenomen in de bundel De eerste en tweede geschiedenis uit 1987. In dit artikel introduceert Smit het onderscheid tussen de eerste en de tweede geschiedenis maar het verschil tussen beide heeft hij naar mijn mening niet helder kunnen maken.

Men kan in Smits verhandeling drie gedachtegangen onderscheiden:

- In eerste instantie betekent eerste geschiedenis voor hem dat alle dingen en verschijnselen bestaan in een zinvolle betrokkenheid op elkaar en op hun goddelijke oorsprong. En de tweede geschiedenis is dan het streven naar verwerkelijking van deze oorsprongsrelatie.

13 Historiche verklaringen kunnen uitgaan van de intenties of motieven van historische actoren. Zo ontstaan intentionele verklaringen. In de geschiedenis spelen echter ook natuurlijke en sociale factoren als van klimaat, bodem, demografie en stand van de techniek een rol. Intentionele handelingen hebben bovendien onbedoelde nevengevolgen. Zulke factoren vragen om causale verklaringen (zie ook Lorenz, 1990:78-95). 
- In het vervolg van zijn betoog biedt Smit een veel negatievere omschrijving van de tweede geschiedenis. De tweede geschiedenis wordt nu "beheerst door een polariteit". Enerzijds is ze aangewezen op de eerste geschiedenis, anderzijds probeert ze zich "af te sluiten" van haar en haar zin. Hij noemt haar nu ook een "tegenbeweging".

- Tot slot treffen we in Smits artikel een derde, formele omschrijving aan. In dit verband noemt hij de tweede geschiedenis de continue geschiedenis van hoe het allemaal geworden is. Hij spreekt ook eenvoudigweg van "de geschiedenis van de historici". 14

Het onderscheid tussen eerste en tweede geschiedenis, zoals ik eerder in mijn betoog aan de orde stelde, spoort met sommige elementen uit de karakteristiek van Smit. Ik zie de eerste geschiedenis als een toevoerkanaal van zin overeenkomstig Smits eerste typering. Ze is immers de voortgaande dialoog met ons verleden, de ontmoetingsruimte voor persoonlijke en collectieve inkeer tot betekenissen van weleer. De tweede geschiedenis zie ik overeenkomstig Smits derde typering als het onderzoeksveld van de historici. Hier is geen sprake van persoonlijke of collectieve inkeer tot de zin der dingen, maar een doorwrochte constructie van het feitelijke verloop der dingen. In de tweede geschiedenis zie ik echter ook een moment van afsluiting, zoals door Smit in zijn tweede typering genoemd. Maar anders dan Smit wil ik dit "afsluiten" zo opvatten dat de geschiedwetenschap niet om negatieve maar om methodische redenen de zinvraag pleegt terug te dringen.

Wij moeten dit methodisch terugdringen van de zinvraag recht verstaan. De geschiedwetenschap is niet waardevrij; ze is altijd geëngageerd, op waarden betrokken. Het is onmogelijk waarden geheel uit het gezichtsveld van de historische onderzoeker te verwijderen. In zijn onderzoeksgebied stuit hij altijd op in de stof aanwezige zinformaties of zinontwikkelingen. Cultuur is zinbeweging; ze is gericht op realisatie van waarden. ledere politieke of godsdienstige gemeenschap, elk arbeids- of familieverband waar de historicus op stuit, representeert en realiseert waarden. Niet de natuur maar de cultuur, niet de bouw van Perikles' woonhuis in Athene maar de totstandkoming van zijn wetgeving acht hij waardevol. Welnu, de historicus moet deze immanente, in de cultuur aanwezige waarden zien te achterhalen en zich toe-eigenen, reeds 
om puur formele redenen. Zonder affiniteit met politiek, economie, moraal en religie zouden hem de criteria ontbreken om politieke, economische, morele en religieuze verschijnselen en handelingen uiteen te houden.

Om die reden lanceerde Heinrich Rickert - als neokantiaan verknocht aan de notie van waardevrije wetenschap - een eeuw geleden de idee dat de geschiedwetenschap niet stoelt op wertende kennis, maar wel op wertbeziehende begripsvorming (Rickert, 1929:339-359; Klapwijk, 1970:163-169). Deze betrekking op waarden zou puur formeel zijn, een betrokkenheid op waarden die in de historische stof zelf te vinden zijn, niet op zelf gekoesterde waarden. Ik deel deze opvatting niet.15 De waardebetrokkenheid van historici is nooit puur formeel. Ze verraadt ook altijd een persoonlijke intentie of een maatschappelijke relevantie. Waarom is het voor ons de moeite waard om onderzoek te doen naar Perikles' wetten, of naar de organisatie van de antieke ziekenzorg, of naar de structuur van de middeleeuwse vroonhoeve? Omdat wij ook tegenwoordig de persoonlijke aandrang of gemeenschappelijke taak ervaren om de staat, de gezondheidszorg en de arbeid te organiseren. In elke cultuurtraditie staat we voor de opgave om op een eigentijdse manier en aangepast aan nieuwe maatschappelijke omstandigheden waarden en idealen gestalte te geven. Deze behoefte aan eigentijdse waardeverwerkelijking motiveert ons om ons te spiegelen aan de waarderealisaties van het voorgeslacht door historisch onderzoek.

De historische methode legt dit onderzoek wel ingrijpende restricties op. Geschiedkundigen zijn geen beleidsmakers. Ze zijn niet geroepen om te overwegen wat van waarde is maar om te bestuderen wat geschied is. Zij willen, zoals alle wetenschappers, voorhanden verschijnselen analyseren en systematiseren, d.i. feiten aan het licht en in een verklarende samenhang brengen. Ook al is hun aandacht voor historisch verwezenlijkte waarden wellicht ingegeven door een diep persoonlijk engagement, ze kunnen dit in

15 Uit de diversiteit van cultuurimmanente waarden wilde Rickert bovenhistorische, universele waarden deduceren. Een speculatieve onderneming want waarden zijn nooit universeel, altijd historisch-relatief. Wel is er affiniteit tussen historische waarden, b.v. tussen het Romeinse en het oud-Germaanse recht. Die affiniteit laat zien dat waarden historisch uiteengegroeide idealen zijn, particuliere realisaties van een universeel normbeginsel, b.v. het beginsel van gerechtigheid. Zo'n normbeginsel zou men bovenhistorisch kunnen noemen. Men kan het universele beginsel echter slechts bevroeden aan de hand van particuliere realisaties. Men kan het nooit deduceren (Klapwijk, 1994:158-192). 
hun feitenrelaas slechts impliciet gestalte geven. Historici zijn niet in een positie om de hen bezielende waarden expliciet in gedachtenis te nemen of expressis verbis uit te dragen, zoals bij voorbeeld in de kerkelijke prediking geschied. ${ }^{16}$ Misschien mag ik mij zo uitdrukken: historisch onderzoek is waardebetrokken, ze is niet waardegericht.

Ik weet het, op dit centrale punt kan men in de theorie van de geschiedenis ook heel andere geluiden horen. Een populaire voorstelling van zaken is deze. De anamnetische geschiedenis is een persoonlijke aangelegenheid. Gedenken verdiept de persoonlijke betrokkenheid van mensen bij de zin der dingen en is dus volstrekt subjectief. De academische geschiedenis is daarentegen een vakmatige, om niet te zeggen, een technische aangelegenheid. Historicaal onderzoek is een academische inspanning van geleerden overal ter wereld tot onpartijdige beschrijving van de feiten. Het biedt een "view from nowhere" (Nagel, 1986) en is dus standpuntvrij en objectief.

Op dit objectivisme, ook naïef realisme genoemd, valt veel af te dingen. Reeds het vaststellen van feiten, zo zagen wij, vergt een waardegezichtspunt. Bovendien is niemand gebaat bij naakte feiten. Het beschrijven van feiten is ook altijd een verklaren van feiten, een zoeken naar verbanden. Het kan geen "technical history" zijn, zoals de Britse geschiedschrijver Herbert Butterfield beweerde, want de rasechte historicus - dat merk je ook in het werk van Butterfield gaat in gesprek met het verleden en geeft zijn persoonlijke kijk op het verleden. Hij of zij ordent en ondervraagt de stemmen uit het verleden maar wil zich ook door deze stemmen laten gezeggen. $\mathrm{Er}$ treedt een hermeneutische cirkel aan het licht. Dat wil zeggen, het verleden willen wij verstaan in het licht van het heden, en dit heden willen wij verstaan tegen de achtergrond van het verleden. Anders dan Butterfield beweerde, is geschiedenis altijd interpretatieve geschiedenis. ${ }^{17}$

Heeft de historische denkwijze een subjectieve kant, het gedenken heeft omgekeerd een objectieve kant. Gedenken berust op een persoonlijke betrokkenheid waardoor wij het verleden ons voor de

16 In het kerkelijke jaarrooster is de zondag "Reminiscere" zelfs expliciet aan het gedenken gewijd.

17 Herbert Butterfield (1900-1979) was een christen-historicus. Niettemin wierp hij zich op als kampioen van een non-interpretatieve of "technical history" als afweer tegen de ideologische propaganda van marxistische en utilitaristische geschiedschrijvers. Zie Sewell (2005, hoofdstuk 8). 
geest halen ten gunste van het heden en voor persoonlijke of collectieve verwerking. Dit engagement brengt inderdaad subjectiviteit en partijdigheid met zich mee, met alle gevolgen van dien, want wie gedenkt, neigt ertoe andermans misstappen uit te vergroten en eigen verleden op te poetsen. Toch gaat gedenken niet blindelings te werk. Wie gedenkt, wil doordringen tot de ware toedracht van zaken. Vergelijk het met verliefdheid. Men zegt wel "verliefdheid maakt blind". Maar beter kan men zeggen "verliefdheid maakt helderziend" want wie verliefd is, ziet iets in de uitverkorene wat aan derden ontgaat. Zo heeft ook wie gedenkt, oog voor wat aan buitenstaanders ontgaat. Gedenken is subjectief en objectief ineen. Neem een vraag als deze: wat heeft het vroegere optreden van Nederland als koloniale grootmacht in Indonesië ons te zeggen? Het antwoord zal subjectief zijn want het komt van mensen die op uiteenlopende manieren betrokken waren bij het koloniale systeem, emotioneel en moreel. Toch heeft het ook een objectieve inhoud, want van diverse zijden wil men de zorg, de strijd, de vreugde en de pijn van het verleden zich klaar voor ogen stellen. Niet de bronnenspecialist maar wie rouwt of viert, voelt de massieve last van de geschiedenis, wanneer hij of zij verklaart: "hiervoor staan wij pal" of "zoiets nooit weer" of "dit moeten wij doorgeven aan het nageslacht".

Natuurlijk, ook een pur sang historicus ervaart verbondenheid met zijn object. Hij heeft een diep respect voor de feiten en wil uitstijgen boven de subjectieve belangen en doelstellingen. Hij brengt "das Interesse an der Geschichte" onder de tucht van de historische kritiek. Hij kritiseert onjuiste voorstellingen en valse claims die zich ooit hechtten aan historische overleveringen. Een opzienbarende aanzet tot objectieve kritiek leverde in de $15 \mathrm{e}$ eeuw de renaissancegeleerde Laurentius Valla. Met zijn filologisch fileermes legde Valla de onechtheid bloot van de tekst van de Donatio Constantini, de vermeende overdracht door keizer Constantijn de Grote (272-337) van het wereldlijke oppergezag in Rome en omstreken aan paus Silvester I als dank voor diens overwinning op Maxentius. Valla's werk was de briljante ontrafeling van een subjectieve en frauduleuze voorstelling van zaken ter legitimatie van het patrimonium Petri, de Kerkelijke Staat in Rome.

Toch snijdt anamnetische kritiek vaak dieper hout dan historische kritiek. Historische kritiek is kritische analyse maar wel vrijblijvend. Valla's bewijsvoering steunde op een zakelijke analyse van voorhanden bronnen maar ontweek de vraag naar politieke consequenties, morele implicaties en religieuze legitimiteit. Wie 
gedenkt, kritiseert eveneens maar dringt tevens aan op daadwerkelijke verandering. Neem de profeet Jesaja ten tijde van de Babylonische ballingschap. Als Jesaja zijn gedachten laat gaan over het godsdienstige verval van Israel, dan is zijn bijtende kritiek tevens een oproep tot ommekeer: "lemand ... kiest een pijnboom ... Met de ene helft stookt hij een vuur, waarop hij vlees bereidt ... Hij wordt warm en zegt: 'Ha, lekker warm ...!' Van de rest maakt hij een god, een godenbeeld waarvoor hij knielt en zich neerbuigt in gebed: 'Red mij, want u bent mijn god"' (Jes. 44:14, 16-17).

Kunnen wij met Cicero stellen: Historia vitae magister? Is de geschiedenis leermeester van het leven? Voor wie gedenkt, is dit geen vraag. In de anamnetische geschiedenis tekenen zich herkenbare patronen en vergelijkbare tendensen af. Zo geldt in haar: wie goed doet, goed ontmoet. En ook: hoogmoed komt voor de val. En ook: eerwraak ontketent een spiraal van geweld. L'histoire se repète. Wij kunnen en moeten inderdaad vergelijkingen maken en leringen trekken uit vroegere voorvallen. Nagedachtenis maakt nadenkend.

Historici zien de zaken anders. L'histoire ne se repète jamais. Uit hun geschiedenis, de academische geschiedenis, kunnen wij geen lessen trekken, noch ter waarschuwing noch ter navolging, want er gaapt dan een kloof tussen verleden en heden. Gebeurtenissen zijn toevallig, feiten uniek, omstandigheden onvergelijkbaar. Doorgaans volgt dan een obligate verwijzing naar de opmerking van Blaise Pascal in zijn Pensées: "Als de neus van Cleopatra korter was geweest, zou de wereld er heel anders hebben uitgezien". (Pascal, 1960 [1670]:2.162). Kortom, van de geschiedenis valt niets te leren.18 Of toch wel? Geeft ze aanleiding tot gedenken? De befaamde Zwitserse historicus Jacob Burckhardt was voorzichtig. Hij zei: geschiedenis maakt niet zozeer klug für ein andermal, als wel weise für immer. Burckhardt weersprak niet het unieke verloop van de geschiedenis, maar was er tevens van doordrongen dat sommige aspiraties in de mens - hij dacht vooral aan nationalistische ambities - telkens terugkeren en ons nadenkend moeten maken.

Vooral Nietzsche had een oog voor de eenzijdigheid van de geschiedwetenschap. Hij voelde het creatieve tekort van historici. In 
Vom Nutzen und Nachteil der Geschichte merkte hij op: "Er is een graad van slapeloosheid, van herkauwen, van historische zin, waarbij het levende geschaad wordt en tot slot te gronde gaat." En ook: "De sprake van het verleden is altijd een orakelspreuk: slechts als bouwmeester van de toekomst, als weet hebbend van het heden, zullen jullie haar verstaan." Vandaar zijn filippica's tegen de krachteloosheid van historische kritiek: "Nergens komt het tot een doorwerking, maar altijd weer slechts tot een 'kritiek'; en deze kritiek heeft zelf weer geen doorwerking, maar ondergaat slechts weer kritiek" (Nietzsche, 1963:2.6, 2.1, 2.5). Niet het resultaat van de historische methode, zeg, de blootgelegde tegenspraak van morele stelsels, leidt tot relativering en resignatie - het probleem schuilt zijns inziens in de historicale methode zelf. Deze obsessieve aandacht voor feiten voert tot vrijblijvendheid. Een kritische élite doet niets anders dan taboes doorprikken en moralisme aan de kaak stellen maar steekt zelf geen hand in het vuur. Dat was voor hem het principiële tekort van de wetenschap.

Soms doet de divergentie tussen de anamnetische herinneringen van een volk en de officiële schrijverij van geschiedkundigen, volstrekt gescheiden circuits ontstaan. Dit was het geval in de vroegere Oostbloklanden. Hoofdthema van de socialistische geschiedenis was de internationale kameraadschap van de arbeidersbeweging ten overstaan van het westerse grootkapitaal. Maar de virulente herleving van ultranationalisme op de Balkan in de jaren negentig heeft laten zien dat in die streken ondergronds altijd een veenbrand is blijven woeden van volstrekt andere herinneringen, traumatische reminiscenties aan een niet verwerkt verleden. De inofficiële geschiedenis op de Balkan ging niet over de solidariteit van socialistische landen. Ze ging over het wrede Ustasja-bewind in de Tweede Wereldoorlog (Jasenovac), over de moord op aartshertog Frans Ferdinand als startpunt van de Eerste Wereldoorlog (Sarajevo, 1914), over de gruwelen van het Ottomaanse rijk in de $19 \mathrm{e}$ eeuw, en over de middeleeuwse strijd van Byzantijnen en Bulgaren tegen de Turken, thans toegespitst op het conflict over Kosovo. 19

19 Het voortslepende conflict over Kosovo tussen Serviërs en etnische Albanezen moet men stellen in het teken van de nederlaag die graaf Lazar leed tegen de moslims in de slag op het Merelveld bij Kosovo Polje (28 juni 1389), de subsequente moord op de Turkse sultan Murat I, en de herwonnen vrijheid van de Serviërs nadien, bekrachtigd in de vrede van San Stefano (1878). Deze strijd is voor de Serviërs uitgegroeid tot een mythisch geloof in eigen volk, cultuur en godsdienst, geworteld in de heilige grond van Kosovo. 
De tegenstelling tussen officiële en anamnetische geschiedenis leeft ook elders voort, bij voorbeeld in het herleefde zelfbewustzijn van de islam. Door terugkeer naar de wortels van hun cultuur en religie trachten islamitische volkeren hun identiteit te herwinnen, langdurig verdrongen door een westers, koloniaal beschavingsperspectief. Tegenspraak tegen de officiële geschiedenis is ook aan de orde in vrouwenbewegingen. Ze manifesteert zich in vrouwenstudies met protesten tegen een machocultuur met eeuwenlang opgedrongen rolpatronen en een mannelijk geschiedenisbeeld, waarin de onafhankelijke geest van vrouwen werd gemarginaliseerd of als hekserij gebrandmerkt. Een soortgelijke tegenspraak trad aan het licht in het protest van Indianen in Latijns Amerika in 1992 tegen de publieke herdenkingen van de ontdekking van Amerika vijfhonderd jaar tevoren. De Indianen kozen voor non-participatie want zij achtten hun lijdensgeschiedenis niet verenigbaar met de officiële weergave van feiten in de post-columbiaanse historiografie.

Over historiografie gesproken, het is niet ongebruikelijk onderscheid te maken tussen de analytisch gerichte geschiedvorsing en de meer synthetisch ingestelde geschiedschrijving, tussen Forschung en Darstellung. Door overheveling van historische feiten uit het argumentatieve naar het narratieve discours wordt geschiedschrijving op die manier tot een vrijere uiteenzetting van feiten en komt ze tegemoet aan de praktische behoefte om te gedenken. Deze neiging is te begrijpen, zeker wanneer dit de contemporaine geschiedenis aanbelangt. Het wordt steeds moeilijker de eis van onpartijdigheid vast te houden hoe meer de eigen tijd in zicht komt. Het historische denkraam gaat interfereren met de eigentijdse interessesfeer. Er treedt zo niet een complete "horizontversmelting" (Gadamer) dan toch een horizontvervaging op. De behoefte tot een dialoog met het verleden neemt toe naarmate het verleden dichterbij komt.

Sommige geschiedschrijvers spelen nadrukkelijk in op de anamnetische behoefte. Ze bieden een dusdanige weergave van feiten dat hun relevantie zichtbaar wordt voor de levenspraktijk; de weergave van feiten gaat gepaard met uitingen van instemming of afkeuring. Een markant voorbeeld van geëngageerde geschiedschrijving leverde Loe de Jong met zijn standaardwerk Het Koninkrijk der Nederlanden in de Tweede Wereldoorlog (De Jong, 1969-1991). Naar het oordeel van anderen, waaronder de historicus J.C.H. Blom, werd de reeks te nadrukkelijk bepaald door opvattingen over goed en fout (Blom, 1983). Een befaamd voorbeeld uit de $19 \mathrm{e}$ eeuw vormt de fijnzinnige verhandeling Über 
die Epochen der neueren Geschichte, een serie voordrachten die Leopold von Ranke in 1854 hield voor koning Maximilan II van Beieren. De voordrachten mondden telkens uit in gesprekken over de tendensen van de geschiedenis en haar betekenis voor het heden (Von Ranke, 1959 [1854]). Ik acht zo'n werkwijze niet onaanvaardbaar mits men publiekelijk erkent dat geschiedschrijving hier ten dele het karakter krijgt van toegepaste wetenschap, rechtstreeks dienstbaar aan de anamnetische levensoriëntatie.

\section{Geschiedwetenschap ten dienste van de anamnetische interesse}

Dit voert me tot mijn slotvraag. Hoe verhoudt zich de anamnetische interesse, ingebed in de eerste geschiedenis, zich tot de academische geschiedenis? Moet de anamnese zich in dienst stellen van de geschiedwetenschap en haar indrukwekkende constructies van de historische werkelijkheid? Of staat de geschiedwetenschap met haar kritische en constructieve inspanningen uiteindelijk in dienst van de anamnetische interesse?

Velen kiezen voor de eerste optie. Uitgaande van het moderne scheidingsdenken, de tegenstelling tussen rede en historische werkelijkheid, geeft men voorrang aan de autonome status en objectieve werkwijze van de geschiedwetenschap. De wetenschap stelt de feiten onomstotelijk vast; laten de mensen daarna maar zien of ze hieraan nog persoonlijke betekenissen kunnen toevoegen. Ik prefereer de andere optie. Wij hebben eerder gezien dat de mens in de praktijk van elke dag bewust of onbewust in geschiedenissen "verstrikt" is. Ook zagen wij dat op de autonomie en objectiviteit van de wetenschap veel valt af te dingen. Wij ontdekten tot slot dat de geschiedwetenschap zelf is opgekomen uit de behoefte aan praktische levensoriëntatie en vroeg of laat de neiging toont weer in te spelen op de anamnetische praxis. Op welke manier zou de geschiedwetenschap deze praxis kunnen dienen?

Ik wil aan het eind van mijn exposé vier hoofdpunten naar voren halen (ze recapituleren tegelijk de kwintessens van mijn betoog tot nu toe): de geschiedwetenschap informeert, verklaart, kritiseert en evalueert ten gunste van de anamnetische praxis.

- De geschiedwetenschap informeert. Mensen zijn eindig van jaren, beperkt van inzicht, en kort van memorie. Herinneringen vervagen of worden verdrongen door ambities en aspiraties. Steunpunten van de traditie, zoals brieven, documenten, dagboeken, klederdrachten, foto's en rituelen houden herinne- 
ringen in stand maar werken ook eenzijdige beeldvorming in de hand. Het zijn de historici die onze herinneringen voeden met broodnodige informatie. $\mathrm{Zij}$ voorzien in een praktische behoefte door zich in te zetten voor gedenkredes, jubileumbundels, historische exposities, tv-documentaires en zoveel meer "opdat wij niet vergeten". 20 De historicale kennis kanaliseert en corrigeert zodoende onze betrokkenheid bij een nabij of ver verleden, en verruimt hiermee de horizont van onze gedachtenis.

- De geschiedwetenschap verklaart. Ze verschaft niet alleen informatie, ze legt ook intentionele en oorzakelijke relaties bloot. Historische ontwikkelingen worden bij voorbeeld gerelateerd aan klimatologische omstandigheden en sociaal-economische ontwikkelingen. Denk eens aan Frankrijk tijdens het ancien régime. Historici konden causale verbanden leggen tussen economische laagconjunctuur (een reeks misoogsten), sociale woelingen en demografische verschuivingen enerzijds, en anderzijds de politieke ideeën die leidden tot de grote revolutie van 1789 . Ik geef toe, de nadruk op oorzakelijke verbanden kan uit de hand lopen en een karikaturaal geschiedenisbeeld oproepen.21 Toch verrijkt de causale verklaring ons oordeel over een zo complex verschijnsel als de Franse revolutie, want in onze gedachtenis wordt deze revolutie te eenzijdig geassocieerd met de ideeën van de Verlichting.

- De geschiedwetenschap kritiseert. Wat in de anamnetische reflectie blijft hangen uit vroegere tijden is vaak vertekend door persoonlijk belang en irrationeel bijgeloof. In de praktische beleving wordt elk geschiedverhaal opgesmukt. Koningen worden godenzonen, krijgers helden, gelovigen heiligen, en tegenstanders veranderen in lafaards, wreedaards en snoodaards. Historische kritiek prikt deze legendes door. Ze zuivert de lucht voor het gedenken. Zo hebben historici bewezen dat in W.O. II niet de Duitsers maar de Russen ruim duizend Poolse officieren vermoordden in de bossen van Katyn. Historici hebben hard

Aldus de titel van Delleman (1949).

$21 \quad$ Ik wijs op de kwantitatieve geschiedschrijving, die de historie strikt causaal wil verklaren. Maar jaartallen, mercurialen, demografische grafieken, economische modellen en contrafactische berekeningen, zoals geproduceerd in de cliometrische studies van de New Economic History (R.W. Fogel, A. Fishlow) en de Histoire quantitative (J. Marczewski, J.-C. Toutain, C.S.), krijgen pas wetenschappelijke waarde binnen een hermeneutische verstaanshorizont (Klapwijk, 1974:194-209). 
gemaakt dat de Amerikaanse president Lyndon Johnson loog toen hij op 4 augustus 1964, ter rechtvaardiging van de geplande aanval op Noord-Vietnam, verklaarde dat Amerikaanse torpedobootjagers in de Golf van Tonkin hadden "teruggeschoten" op Noord-Vietnamese patrouilleboten. Historici hebben aangetoond dat het eeuwenlange conflict tussen joden en christenen geen Bijbelse oorsprong had, laat staan christelijk antisemitisme rechtvaardigt; ze zette eerst in na de verwoesting van Jeruzalem (70 n.C.).

- De geschiedwetenschap evalueert. Anders dan het gedenken is de wetenschappelijke benadering van de geschiedenis niet in expliciete zin waardegericht. De onderzoeker schort zijn eigen waardeoordeel zoveel mogelijk op en verdiept zich in de waardepatronen die inherent zijn (of waren) aan de betrokken cultuur. Toch resoneren die waardepatronen ook in zijn eigen bewustzijn; hij kan ze niet losmaken van hedendaagse interesses, van waarden die op dit moment de gemoederen bezighouden. Ik noem als voorbeeld milieuwaarden. Zo is het vruchtbaar gebleken om vanuit een modern, ecologisch gezichtspunt de vraag te stellen waarom vanaf 900 n.C., dus ver voor de komst van de Spaanse conquistadores, de Maya-indianen hun welvarende steden in Yucatán zonder enig spoor van geweld in korte tijd verlaten hebben. Er komen aanwijzingen naar boven dat de catastrofe die zich indertijd in deze steden voltrok, samenhing met bodemuitputting en falend watermanagement. Kortom, een wetenschap die echt wil ingaan op historische feiten is een wetenschap die het vroegere waardeoordeel (de vloek der goden e.d.) niet klakkeloos repeteert maar vanuit nieuwe vraagstellingen revalueert.

Al met al is het geen wonder dat elke nieuwe tijd zijn historie herschrijft, ja, moet herschrijven. Oudere studies ervaren we als achterhaald, niet omdat ze fout zijn, maar omdat ze minder relevant zijn. Boeken van weleer over monarchale, politieke, militaire of diplomatieke geschiedenis laten wij liggen, want andere zaken gaan ons tegenwoordig ter harte dan de eer van vorst, volk, vaandel of vaderland. Sociale interesse doet ons vragen naar de mensonterende omstandigheden waarin de lagere standen verkeerden ten tijde van de Franse revolutie. Feministische interesse doet ons vragen naar de gemarginaliseerde positie van vrouwen in voorgaande tijden en naar het fenomeen van hekserij. Respect voor mensenrechten maakt ons geïnteresseerd in studies over inquisitie, gezondheidszorg, en rechtspleging in vroegere eeuwen. Wij hebben 
namelijk in de afgelopen decennia ontdekt dat gedenken zich ook uit in mededogen met ketters, krankzinnigen en criminelen.

Ik kom tot mijn slotopmerking. Er is een niet gering verschil tussen de anamnetische en de historicale interesse, zo ook tussen de geleefde en de geconstrueerde geschiedenis. De geleefde geschiedenis gaat vooraf aan de wetenschappelijk geconstrueerde geschiedenis, niet alleen in tijd maar ook in rang. Geen wonder. Het leven is er niet omwille van de wetenschap. De wetenschap is er omwille van het leven, een leven waarin wij omzien naar anderen, ook door ze te gedenken. Gedenkend dragen wij onze herinneringen met ons mee, maar niet als losse legpuzzelstukjes ter completering van het werkelijkheidsbeeld dat de historici zo vlijtig ontwerpen. Integendeel, laat de historici hun beeld van de geschiedenis construeren ter wille van ons opdat wij, verwikkeld in de geschiedenis, beter toegerust zijn om te overdenken wie wij zijn, waar wij vandaan komen, en waar wij naar toe willen.

\section{Geraadpleegde werken}

BLOM, J.C.H. 1983. In de ban van goed en fout? Wetenschappelijke geschiedschrijving over de bezettingstijd in Nederland. Amsterdam: Universiteit van Amsterdam. (Inaugurele rede.)

BUBER, M. 1974 [1923]. Ich und Du. (In Das dialogische Prinzip. Heidelberg: Lambert Schneider.)

BUIJS, G.J. 1998. Tussen God en duivel: totalitarisme, politiek en transcendentie. Amsterdam: Boom.

DE JONG, L. 1969-1991. Het koninkrijk der Nederlanden in de Tweede Wereldoorlog. 14 delen. Den Haag: SDU.

DELLEMAN, T., red. 1949. Opdat wij niet vergeten: de bijdrage van de Gereformeerde Kerken ... in het verzet tegen het nationaal-socialisme en de Duitse tyrannie. Kampen: Kok.

FUKUYAMA, F. 1992. The end of history and the last man. London: Penguin Books.

GADAMER, H.-G. 1965. Wahrheit und Methode. 2. Aufl. Tübingen: Mohr.

HEGEL, G.W.F. 1952 [1807]. Phänomenologie des Geistes. 6. Aufl. Hamburg: Felix Meiner.

JASPERS, K. 1949. Vom Ursprung und Ziel der Geschichte. München: Piper.

JONKER, E. 1992/1993. De neus van Cleopatra. Wijsgerig Perspectief, 33:8186.

KLAPWIJK, J. 1970. Tussen historisme en relativisme: een studie over de dynamiek van het historisme en de wijsgerige ontwikkelingsgang van Ernst Troeltsch. Assen: Van Gorcum.

KLAPWIJK, J. 1974. Methoden-strijd in de geschiedeniswetenschap. Algemene Nederlandsche Tijdschrift voor Wijsbegeerte, 66:194-209.

KLAPWIJK, J. 1994. Pluralism of norms and values: on the claim and reception of the universal. Philosophia Reformata, 59:158-192. 
LORENZ, Ch. 1990. De constructie van het verleden: een inleiding in de theorie van de geschiedenis. 2e druk. Meppel: Boom.

NAGEL, Th. 1986. The view from nowhere. Oxford: Oxford University Press.

NIETZSCHE, F. 1963. Unzeitgemässe Betrachtungen. 2: Vom Nutzen und Nachteil der Historie. p. 209-285. Werke I. Darmstadt: Wissenschaftlichen Buchgesellschaft.

PASCAL, B. 1960 [1670]. Pensées. Paris: Seuil.

RICKERT, H. 1929. Die Grenzen der naturwissenschaftlichen Begriffsbildung: eine logische Einleitung in die historischen Wissenschaften. 5. Aufl. Tübingen: Mohr.

SCHAAP, S. 2001. Het onvermogen te vergeten: Nietzsche's herwaardering van de waarheidsvraag. Budel: Damon.

SCHAPP, W. 1953. In Geschichten verstrickt: zum Sein von Mensch und Ding. Hamburg: Meiner.

SEWELL, K.C. 2005. Herbert Butterfield and the interpretation of history. New York: Palgrave Macmillan.

SMIT, M.C \& Klapwijk, J., red. 1987. De eerste en tweede geschiedenis: nagelaten geschriften van Meijer C. Smit. Amsterdam: Buijten \& Schipperheijn.

TOYNBEE, A.J. 1946. Civilization on trial. London: Oxford University Press.

TROELTSCH, E. 1961 [1922]. Der Historismus und seine Probleme. Aalen: Scientia.

VOEGELIN, E. 1956; 1974; 1987. Order and history. Vols. 1, 4 \& 5. Baton Rouge: Lousiana State University Press.

VOEGELIN, E. 1966. Anamnesis: zur Theorie der Geschichte und Politik. München: Piper.

VON RANKE, L. 1959 [1854]. Über die Epochen der Weltgeschichte: Vorträge dem Könige Maximilian II von Bayern gehalten. Darmstadt: Wissenschaftlichen Buchgesellschaft.

WHO. 2002. World Report on Violence and Health. Geneva: World Health Organization.

WITTRAM, R. 1963. Das Interesse an der Geschichte: zwölf Vorlesungen über Fragen des zeitgenössischen Geschichtsverständnisses. Göttingen: Vandenhoeck \& Ruprecht.

\section{Kernbegrippen:}

anamnetische interesse

eerste en tweede geschiedenis

gedenken

herdenken

historiese waarde

\section{Key concepts:}

anamnetic interest

commemoration

first and second history

historical values

remembrance 